\title{
CARACTERIZAÇÃo dOS FRUTOS, SEMENTES E GERMINAÇão DE QUATRO ESPÉCies de Leguminosas da Restinga de Maricá, Rio de JANEIro ${ }^{1}$
}

\author{
Isabele Pagels Gonçalves ${ }^{2}$, Michele da Costa Gama², \\ Maria Célia Rodrigues Correia ${ }^{2,3}$ \& Heloísa Alves de Lima ${ }^{2}$
}

\begin{abstract}
RESUMO
(Caracterização dos frutos, sementes e germinação de quatro espécies de leguminosas da restinga de Maricá, Rio de Janeiro) No presente trabalho foi estudada a morfologia dos frutos e das sementes e características de plântulas de: Canavalia rosea, Ormosia arborea, Pithecellobium tortum e Swartzia apetala var. apetala, de janeiro de 2004 a outubro de 2006, na restinga de Maricá, Rio de Janeiro. As espécies possuem frutos deiscentes com dispersão autocórica. As sementes de $S$. apetala var. apetala sugerem também dispersão zoocórica pela presença de um arilo. As sementes recém-coletadas apresentam médias altas de germinação: C. rosea (99\%), O. arborea (100\%), P. tortum (75\%) e S. apetala var. apetala (93\%), entretanto, no habitat natural, só foram encontradas plântulas de $C$. rosea. A germinação é criptocotiledonar em $O$. arborea e $S$. apetala var. apetala e fanerocotiledonar em $C$. rosea e P. tortum.

Palavras-chave: Leguminosae, Fabaceae, morfologia, fisiologia de sementes, dispersão de sementes, Canavalia, Ormosia, Pithecellobium, Swartzia.
\end{abstract}

\begin{abstract}
(Fruit, seed and seedling studies of four species of legume in the restinga of Maricá, Rio de Janeiro) The morphology of fruits, seeds and seedlings of Canavalia rosea, Ormosia arborea, Pithecellobium tortum and Swartzia apetala var. apetala in the "restinga" of Maricá, state of Rio de Janeiro was studied between January 2004 and October 2006. All species present dehiscent fruits and autochorous dispersial, but the seeds of $S$. apetala var. apetala also suggest zoochorous dispersial by the presence of an aril. Newly collected seeds show high germination success: C. rosea (99\%), O. arborea (100\%), P. tortum (93\%) and $S$. apetala var. apetala (75\%), however, the only seedlings found in the natural habitat were of C. rosea. Cryptocotylar seedling was recorded for $O$. arborea and $S$. apetala var. apetala. while phanerocotylar seedling was observed in $C$. rosea and P. tortum.
\end{abstract}

Key words: Leguminosae, Fabaceae, morphology, seed physiology, seed dispersal. Canavalia, Ormosia, Pithecellobium, Swartzia.

\section{INTRODUÇÃo}

Leguminosae, uma das maiores famílias dentre as angiospermas, apresenta ampla distribuição geográfica e tem incalculável importância econômica (Arroyo 1981). Pereira \& Araújo (2000) e Pereira et al. (2001) destacam-na como a mais importante família botânica das restingas dos estados do Espírito Santo e Rio de Janeiro, com 96 espécies. A predominância das leguminosas é também assinalada em vários levantamentos florísticos: nas florestas tropicais por Gentry (1982), na mata atlântica por Barros et al. (1991) e no
Parque Nacional da Restinga de Jurubatiba, que envolve os municípios de Carapebus, Quissamã e Macaé (Araújo et al. 2001). Na restinga de Maricá, a família está representada por 28 espécies (Silva \& Oliveira 1989).

Pesquisas sobre a germinação de sementes e o conhecimento morfológico de plântulas podem fornecer uma ferramenta de grande utilidade na identificação de espécies, além de complementar estudos de ecologia, agronomia e taxonomia (Parra 1984, Oliveira 1993, Silva 2003). Segundo Oliveira (2001), devido ao grande número de espécies de leguminosas, fica

Artigo recebido em 10/2007. Aceito para publicação em 04/2008.

${ }^{1}$ Parte do projeto "Germinação das sementes e caracterização das plântulas de espécies das restingas do estado do Rio de Janeiro".

${ }^{2}$ Laboratório de Biologia Reprodutiva, Departamento de Botânica do Museu Nacional/UFRJ, Quinta da Boa Vista s/nº, São Cristóvão, 20940-040, Rio de Janeiro, RJ, Brasil.

${ }^{3}$ Autor para correspondência: mcorreia@acd.ufrj.br 
evidente a existência de problemas taxonômicos e impasses filogenéticos, que a análise tradicional de órgãos vegetativos e florais é insuficiente para solucionar. Desta forma, a autora salienta a importância de estudos de frutos, sementes, plântulas e plantas jovens, não somente com propósitos taxonômicos, filogenéticos ou ecológicos, mas, sobretudo, como contribuição para o conhecimento das espécies desta família.

Informações sobre a germinação das sementes de restinga podem contribuir para a preservação das espécies neste ecossistema e são essenciais para proteger muitas espécies contra a ameaça de extinção. $\mathrm{O}$ reconhecimento de plântulas e de plantas jovens no ecossistema restinga pode ser de grande valor para estabelecer a dinâmica de populações presentes, já que a fase de plântula é crítica e pouco conhecida, principalmente para este ambiente (Zamith \& Scarano 2004).

As restingas são ecossistemas muito bem representados em todo o litoral do Brasil. Porém, apesar de ser um tipo de ambiente único, de imensa biodiversidade e de beleza natural, é muito descaracterizado ou até, por muitas vezes, totalmente dizimado. Em virtude da localização privilegiada, a restinga sofre com a especulação imobiliária em grande escala, que vem alterando significativamente tanto a estrutura da vegetação como a composição florística.

Neste contexto, este trabalho visa conhecer as médias de germinação e os estudos de desenvolvimento das plântulas de: Canavalia rosea (feijão-da-praia" ou "cipóda-praia"), Ormosia arborea ("olho-decabra", "olho-de-boi" ou "pau-ripa"), Pithecellobium tortum ("vinhático-deespinho") e Swartzia apetala.

\section{Material e Métodos}

Os trabalhos de campo compreenderam excursões quinzenais à área de estudo, de janeiro/2004 a outubro/2006, para: demarcação das áreas de observação; registro dos períodos de floração e de frutificação e acompanhamento destes eventos; coleta de frutos maduros e de sementes; e localização de plântulas das espécies em estudo, sendo realizada uma varredura de cerca de $1 \mathrm{~km}^{2}$ na área de ocorrência das espécies, incluindo moitas e áreas desnudas.

Os frutos obtidos de polinizações naturais (controle) das espécies em estudo foram ensacados com sacos de filó no início do desenvolvimento e mensurados a cada excursão. Quando maduros, os frutos foram analisados quanto ao tamanho e quantidade de sementes. As sementes foram contadas, mensuradas e analisadas sob microscópio estereoscópio. Foram consideradas sementes viáveis aquelas que continham embrião; e abortadas ou inviáveis as mal formadas, muito pequenas ou sem embrião. Para $C$. rosea foi avaliada a incidência de formação de frutos ao longo da inflorescência ( $\mathrm{N}=181$ frutos).

Para a germinação das sementes e desenvolvimento de plântulas foram efetuados experimentos em condições ambientais. Sementes foram colocadas para germinar em placas de Petri com15 cm de diâmetro, forradas com papel de filtro e umedecidas com água destilada. Para $C$. rosea também foram usados substratos de vermiculita, areia e terra vegetal. Os experimentos foram acompanhados diariamente e mantidos umedecidos com água destilada, durante todo o período em que houve germinação de sementes.

As sementes usadas nos experimentos de germinação foram retiradas, manualmente, de vários frutos e colocadas para germinar nos dias subsequientes às coletas de campo. O número das sementes em cada amostra variou de 12 a 37, de acordo com a disponibilidade das mesmas.

Considerou-se o início da germinação como a data em que há o rompimento dos tegumentos e a emergência da raiz principal. A definição de plântula usada foi a de Parra (1984), que inclui todos os estádios de desenvolvimento desde a emergência da raiz principal até o aparecimento do primeiro 
metáfilo. Cada estádio do desenvolvimento foi desenhado ou fotografado e anotado o número de dias decorridos, nesta ordem: aparecimento da raiz principal, dos cotilédones, das primeiras folhas, do tempo que os cotilédones ficam exauridos e secam.

$\mathrm{Na}$ germinação das sementes de $O$. arborea, que possuem tegumento resistente, além de sementes sem nenhum tratamento foram testadas sementes escarificadas (lixadas). Para o teste com sementes de $S$. apetala var. apetala, o arilo que envolve o tegumento da semente foi retirado manualmente. Para a germinação das sementes de $C$. rosea foram ainda realizados outros dois experimentos: 1 . Sementes coletadas diretamente da areia no habitat natural: sementes expostas ao sol intenso, ventos e chuvas, por um período não determinado ( $\mathrm{N}=37) ; 2$. Testes de soterramento de sementes em laboratório: sementes foram colocadas para germinar no fundo de copos, com substrato de areia (trazida da restinga de Maricá), a profundidades de $5 \mathrm{~cm}(\mathrm{~N}=5), 10$ $\mathrm{cm}(\mathrm{N}=5)$ e $20 \mathrm{~cm}(\mathrm{~N}=5)$.

Plântulas de C. rosea, com cerca $30 \mathrm{~cm}$ de altura, foram transplantadas para canteiros (expostas diretamente à luz do sol), e para sacos plásticos mantidos em casa de vegetação (expostas a mais sombreamento). $\mathrm{O}$ substrato usado foi uma mistura de terra vegetal com areia da praia. Após 35 dias, cinco plântulas de $C$. rosea dos canteiros e da casa de vegetação foram analisadas quanto ao sistema radicular.

\section{Resultados}

\section{Canavalia rosea (Sw.) DC.}

$\mathrm{Na}$ restinga de Maricá $C$. rosea é uma leguminosa muito freqüente na zona psamófita-reptante. Nesta comunidade, divide seu habitat principalmente com Iresine portulacoides Moq. (Portulacaceae), Sporobulus virginicus Kunth (Poaceae), Pilosocereus arrabidae (Lem.) Byles \& Rowl (Cactaceae), Ipomoea pes-caprae (L.) Sweet e Ipomoea imperati (Vahl) Griseb. (Convolvulaceae).
Canavalia rosea por apresentar hábito estolonífero, folhas trifolioladas de cor verde clara e flores rosa destaca-se bem entre as outras plantas da zona psamófita-reptante. Seu hábito permite que ramificações cresçam em direção à comunidade de halófitas onde ficam mais expostas às águas das marés e à forte ação eólica.

As flores de C. rosea são zigomorfas, hermafroditas, nectaríferas, odoríferas (odor doce bem suave) e reúnem-se em inflorescências racemosas do tipo cacho. A espécie apresenta floração nos meses de março a maio, destacando-se um número maior de flores em fim de março e abril; o desenvolvimento dos frutos ocorre de março a junho.

Os frutos de C. rosea são legumes, com média de $12,4 \mathrm{~cm}$ de comprimento $(\mathrm{N}=100$; $\mathrm{dp}=1,90$ ), de pericarpo grosso e de coloração verde por todo seu desenvolvimento, que se estende por quatro meses (Fig. 1a). Ao fim deste período, o fruto apresenta a cor marrom, entretanto, permanece ainda preso à inflorescência por mais um ou dois meses (Fig. 1b), quando racha, expondo as sementes e dispersando-as sobre o solo da restinga (Fig. $1 \mathrm{c}, \mathrm{d}, \mathrm{e})$.

A formação dos frutos no eixo da inflorescência varia, sendo observados $51 \%$ de frutos na base, $28 \%$ no centro e $21 \%$ no ápice ( $\mathrm{N}=181$ frutos). O número de sementes por fruto apresenta média de 6,59 $(\mathrm{N}=100$; $\mathrm{dp}=1,23$ ). As sementes são ovóides com tegumento espesso de coloração castanha, com pequenas manchas de tonalidade mais clara (Fig. 2a, a') e medem em média 1,5 cm de comprimento $(\mathrm{N}=10 ; \mathrm{dp}=0,05)$.

\subsection{Desenvolvimento das plântulas de Canavalia rosea}

Sementes recém coletadas de frutos maduros de $C$. rosea apresentaram percentuais altos de germinação em todos os substratos testados: 96,6\% em papel de filtro $(\mathrm{N}=30)$, $100 \%$ em areia $(\mathrm{N}=18), 100 \%$ em terra vegetal $(\mathrm{N}=18)$ e $100 \%$ em vermiculita $(\mathrm{N}=12)$. 

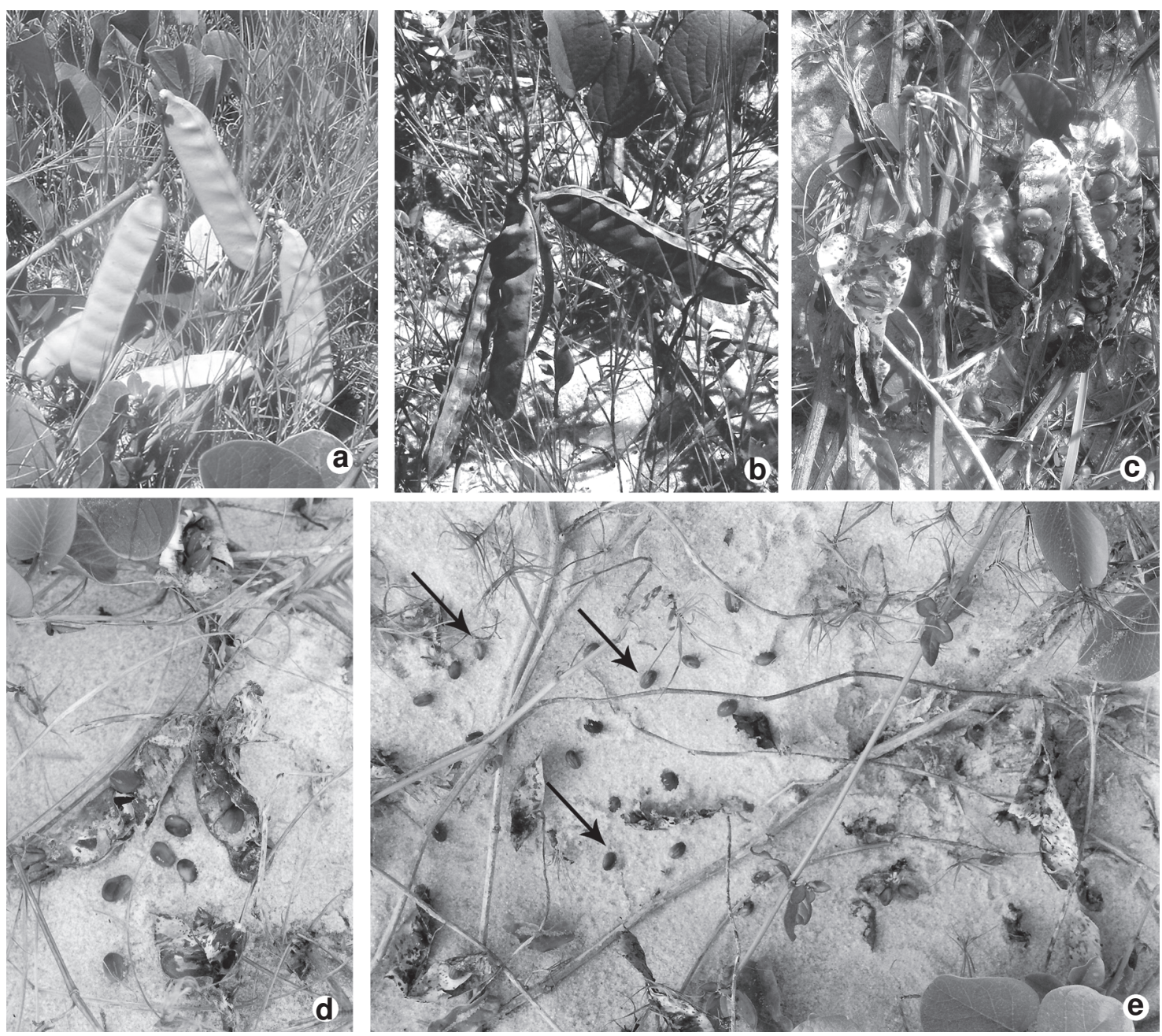

Figura 1 - a-e. Canavalia rosea (SW.) DC. - a. frutos em desenvolvimento; b. frutos maduros; c. frutos abertos liberando as sementes; d. frutos em decomposição na areia; e. sementes dispersas na areia (setas).

Canavalia rosea apresenta germinação fanerocotiledonar, rompendo o tegumento e emitindo a raiz principal em torno de dois dias (Fig. 2b). As sementes quando colocadas para germinar absorvem muita água, dobrando seu tamanho (Fig. 2b). O hipocótilo é crasso, tem tonalidade verde-clara e seu crescimento é muito rápido (Fig. 2c-d). Com seis dias, a plântula mostra uma curvatura típica do hipocótilo, em forma de joelho, iniciando-se a liberação dos cotilédones (Fig. 2e). Plântulas com oito dias, apresentam $12 \mathrm{~cm}$ de altura, cotilédones liberados e raízes secundárias (Fig. 2f). Os cotilédones são verdes, carnosos e medem $2,5 \mathrm{~cm}$ de comprimento. Quando os cotilédones encontram-se totalmente livres do tegumento, surgem os eófilos. A plântula com 11 dias mede $22 \mathrm{~cm}$ de altura; nesta fase os eófilos encontram-se totalmente expandidos (Fig. 2g). Logo a seguir os cotilédones caem (Fig. 3h). Os eófilos apresentam filotaxia oposta, forma cordiforme com nervação bem marcante, bordos lisos e na base do pecíolo um pulvínulo (Fig. 3h'). A plântula com 13 dias mede $24 \mathrm{~cm}$ de altura, apresenta sistema radicular com algumas ramificações, eófilos e folhas definitivas (Fig. 3i). Os metáfilos são trifoliolados, têm pecíolos longos e estípulas pequenas e triangulares. O segundo metáfilo surge pouco depois, com 17 dias (Fig. 3j). 


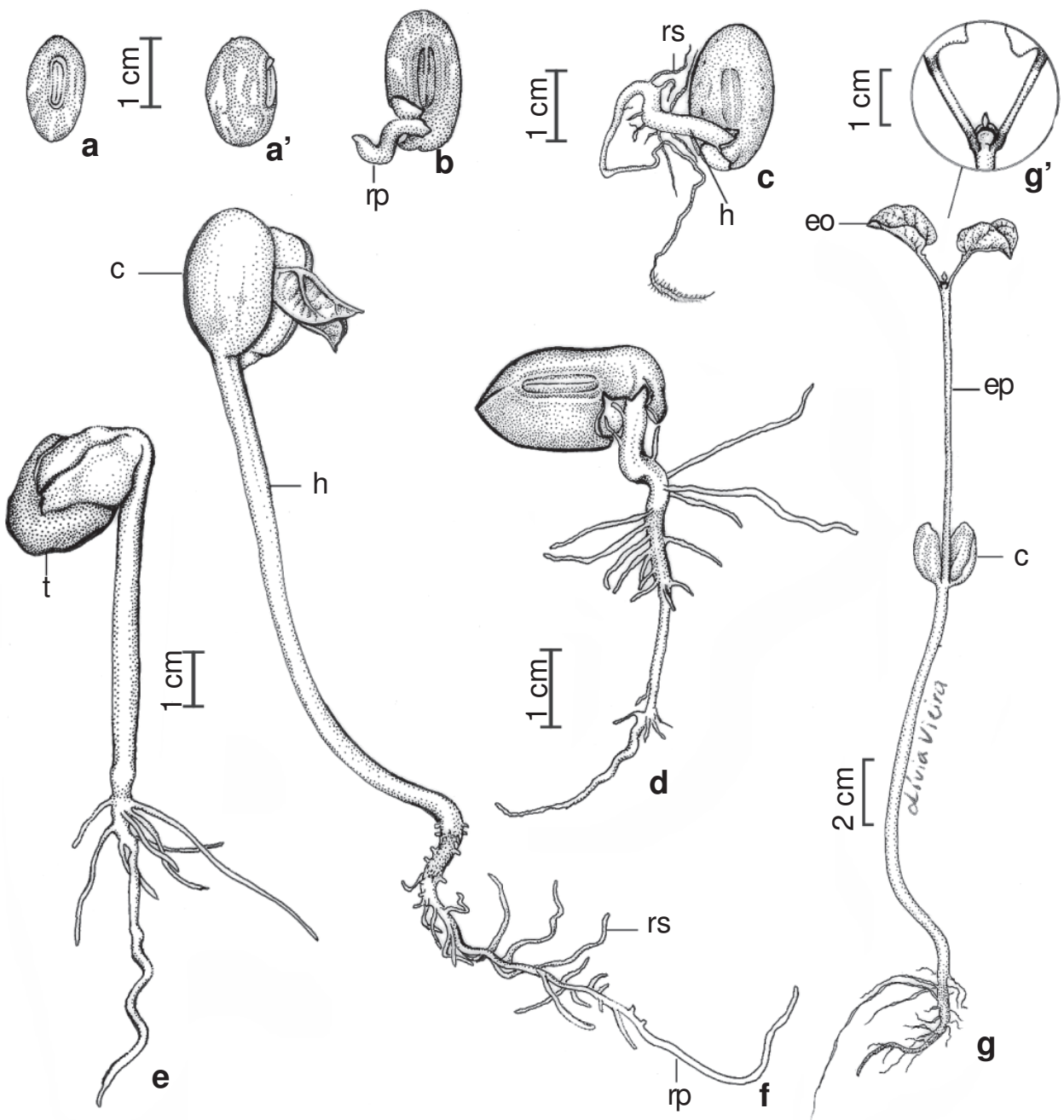

Figura 2 - Desenvolvimento da plântula de Canavalia rosea (Sw.) DC. - a. semente em vista frontal; a'. semente em vista lateral; b. Ssemente com aproximadamente o dobro do tamanho natural, com cerca de 2 dias de germinada, mostrando emissão da raiz principal (rp); c. plântula com 4 dias mostra o hipocótilo (h) e surgimento de raízes secundárias (rs); d. plântula com 5 dias com o tegumento da semente se soltando; e. plântula com 6 dias, mostra a curvatura típica do hipocótilo e início da liberação dos cotilédones ainda presos ao tegumento (t); f. plântula com 8 dias, tem os cotilédones livres (c) e início da emissão dos eófilos; g. plântula com 11 dias tem um epicótilo fino (ep), eófilos totalmente distendidos (eo) e início da senescência dos cotilédones (c); g'. detalhe das estípulas presentes entre os eófilos.

Os metáfilos podem surgir tanto da base da inserção dos eófilos quanto de uma haste solitária da mesma inserção (Fig. 3i, j).

Nos experimentos de germinação com sementes coletadas diretamente na areia, a média de germinação registrada foi $84 \%$ $(\mathrm{N}=37)$, num período de 314 dias.

Os experimentos de germinação com sementes soterradas apresentaram $100 \%$ de germinação quando soterradas a $5 \mathrm{~cm}$ de profundidade, $80 \%$ quando soterradas a $10 \mathrm{~cm}$ de profundidade e $0 \%$ (nenhuma semente germinada) quando soterradas a $20 \mathrm{~cm}$.

No ambiente natural foram registradas plântulas de $C$. rosea em várias fases de desenvolvimento, com emissão da raiz principal, com os cotilédones e com as primeiras folhas tanto na zona de psamófita-reptante quanto na zona de halófitas (Fig. 4a-c). Nesta última, as plântulas encontravam-se soterradas entre 5 a $10,5 \mathrm{~cm}$ de profundidade (Fig. 4d). 


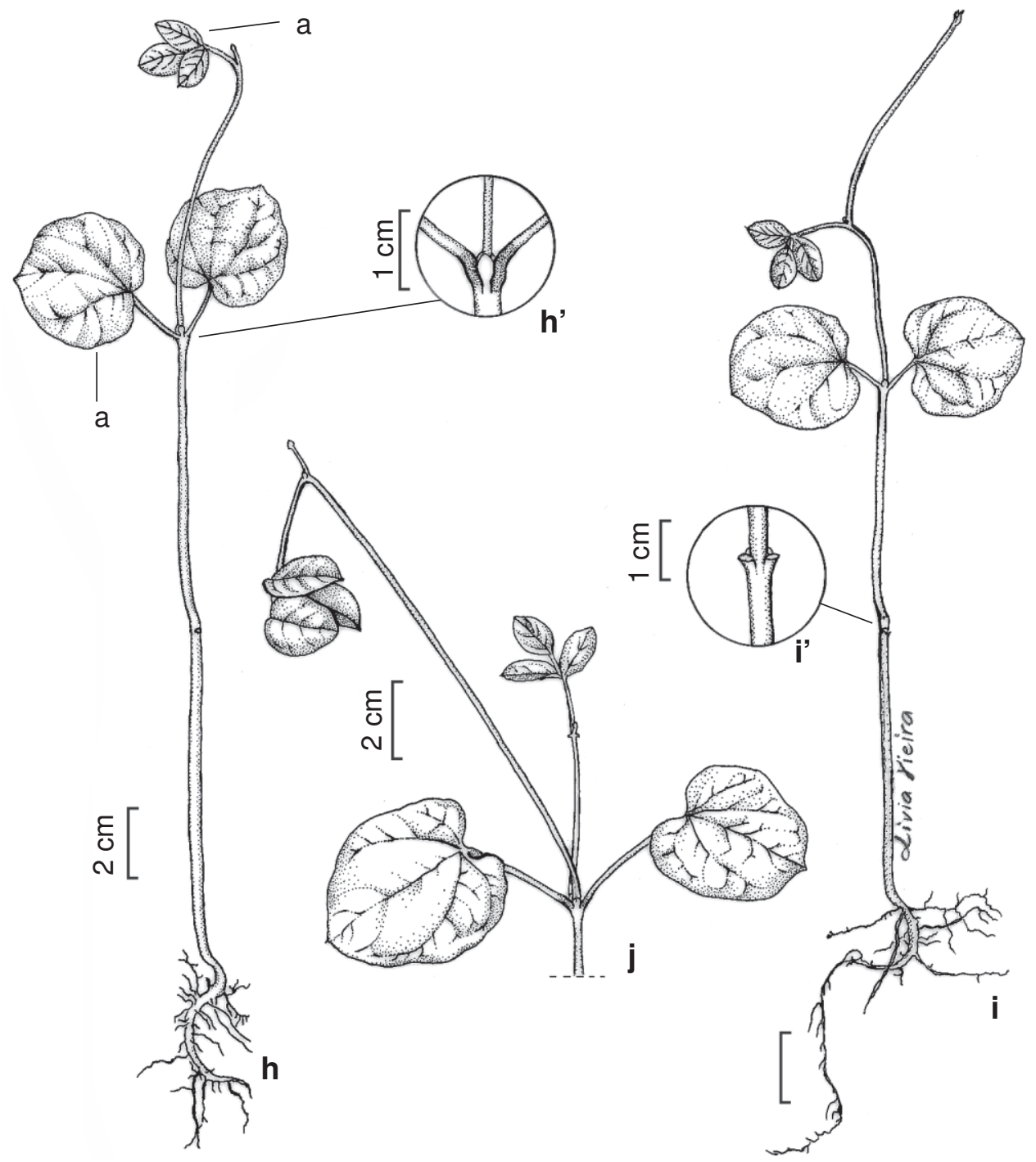

Figura 3 - Desenvolvimento da plântula de Canavalia rosea (Sw.) DC - h. plântula com 15 dias mostra os eófilos (eo) completamente desenvolvidos e o início de formação dos metáfilos (m). Neste estádio a plântula perde os cotilédones; h'. detalhe dos pulvínulos dos eófilos; i. plântula com 17 dias apresenta eófilos e metáfilos; i'. detalhe da cicatriz dos cotilédones; j. detalhe do par de eófilos e dos metáfilos trifoliolados. A plântula nesta fase tem 23 dias e uma altura $40 \mathrm{~cm}$.

Plântulas de C. rosea cultivadas em canteiros expostos diretamente à luz do sol apresentam nódulos radiciais com cerca de um mês de idade (Fig. 4e).

\section{Ormosia arborea (Vell.) Harms}

Ormosia arborea é uma árvore que se localiza no cordão arenoso interno da restinga de Maricá. As flores de O. arborea são zigomorfas, hermafroditas, nectaríferas, levemente odoríferas e reúnem-se em inflorescências racemosas do tipo cacho. Apresenta floração subanual envolvendo os meses de novembro/dezembro/janeiro e os frutos amadurecem, paulatinamente, de fevereiro a outubro/novembro, podendo permanecer já maduros na árvore por alguns meses. Os legumes variam de 3,5 a $8,5 \mathrm{~cm}$ de comprimento e 2,5 a $3 \mathrm{~cm}$ de largura $(\mathrm{N}=30)$, de acordo com o número de sementes (1-4) 

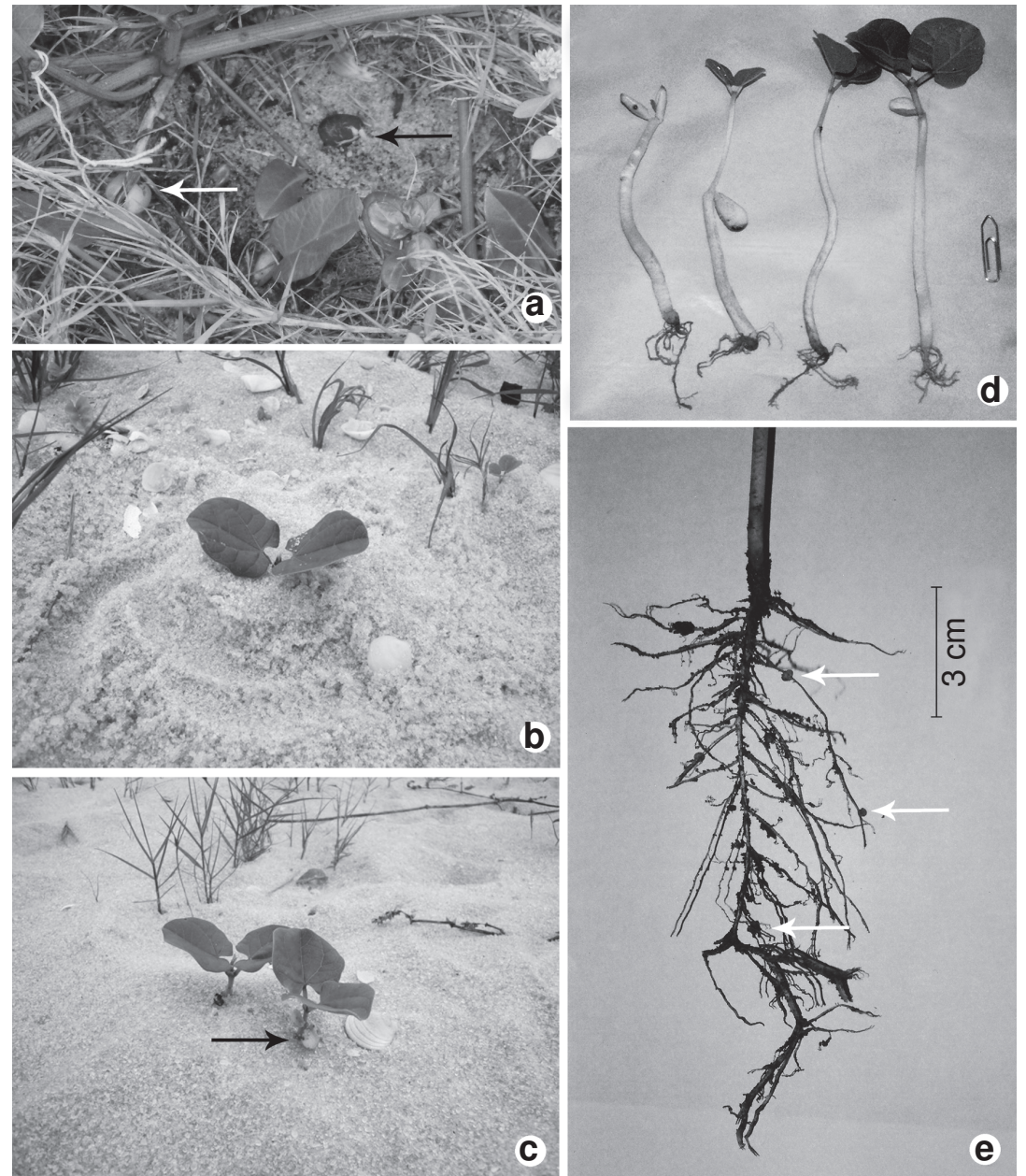

Figura 4 - Plântulas de Canavalia rosea (Sw.) DC. - a. na zona psamófita-reptante, com emissão da raiz principal e com os cotilédones (setas); b-c. na zona halófita, soterradas, mostrando os eófilos; d. seqüência de germinação encontrada na zona halófita, notar a espessura e a tonalidade clara do hipocótilo e dos cotilédones; e. detalhe dos nódulos radiciais (setas) em plântulas cultivadas nos canteiros do Horto Botânico do Museu Nacional, com cerca de um mês.

presentes em cada fruto (Fig. 5a-e). Ocorre alto índice de aborto de sementes e de óvulos (Fig. 5b, d, e). As sementes são bicolores (abóbora, parte mais extensa, e preta, Fig. 6a) e apresentam média de $1,2 \mathrm{~cm}$ de comprimento $(\mathrm{N}=30, \mathrm{dp}=0,14)$.

\subsection{Desenvolvimento das plântulas de Ormosia arborea}

O percentual de germinação das sementes de $O$. arborea foi alto, tanto em sementes escarificadas $(100 \%, \mathrm{~N}=12)$, quanto em sementes não escarificadas $(90 \%, \mathrm{~N}=11)$. A germinação é criptocotiledonar com emissão da raiz principal em cerca de 9 a 12 dias, respectivamente, em sementes escarificadas e não escarificadas (Fig. 6b). O epicótilo é cilíndrico, de cor verde clara, tem superfície pilosa e apresenta crescimento bem rápido (Fig. 6c-f). Os cotilédones são verdes e crassos. A plântula com 26 dias mede $12 \mathrm{~cm}$ de altura, apresenta sistema radicular pouco desenvolvido com algumas raízes secundárias e os eófilos (Fig. 6g, h). Estes apresentam filotaxia oposta, forma elíptica com nervuras bem marcantes e bordos ondulados (Fig. 6i, j). Uma plântula com 50 dias mostra a formação do terceiro eófilo, um 

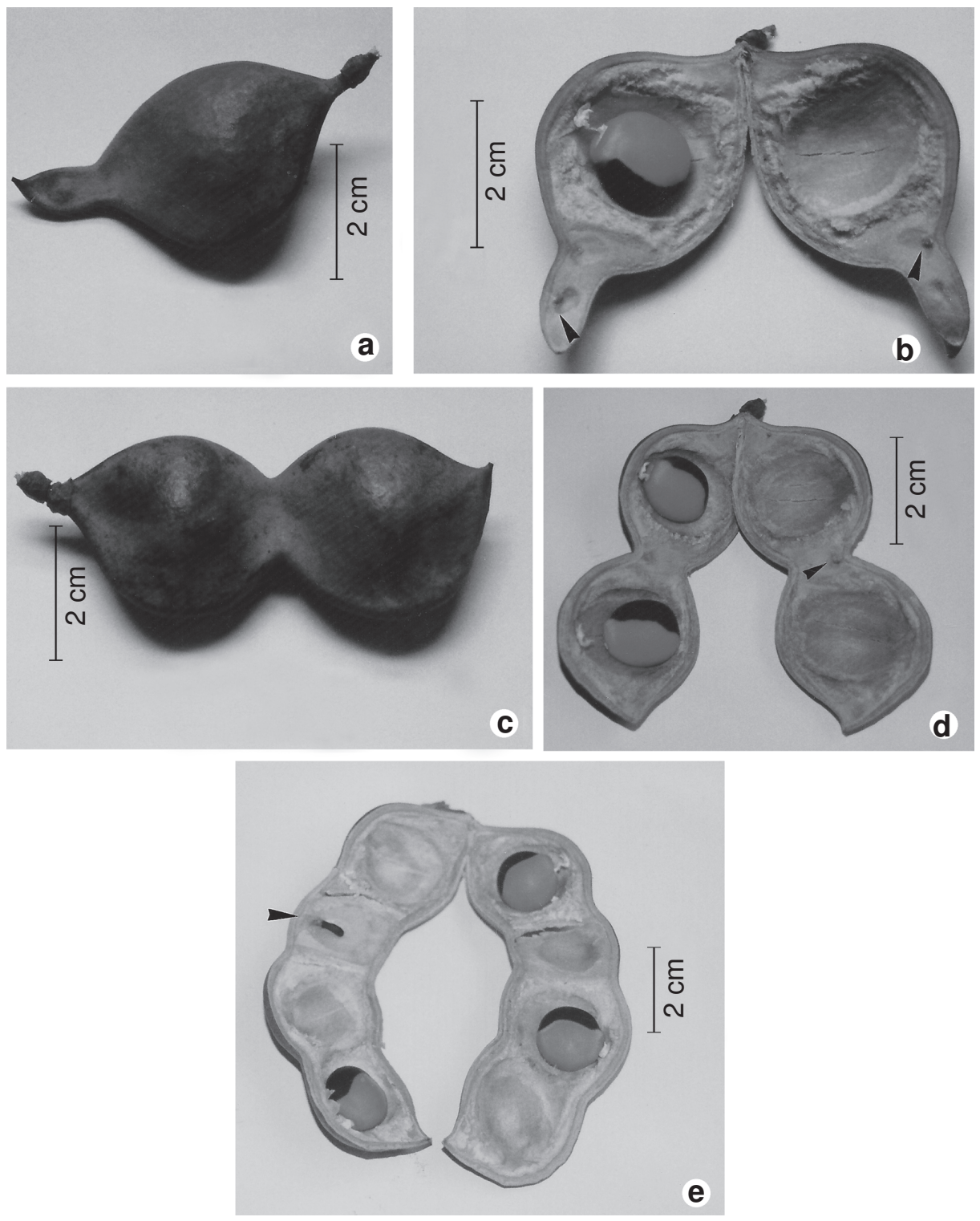

Figura 5 - Frutos de Ormosia arborea (Vell.) Harms. - a, c. frutos fechados; b, d. frutos abertos mostrando uma e duas sementes e óvulos não fecundados (setas); e. fruto aberto com três sementes e uma semente abortada (seta).

sistema radicular mais desenvolvido e ainda a presença dos cotilédones, porém já bem diminuídos (Fig. 6k). Com 70 dias os cotilédones murcham. Não foram registradas plântulas de $O$. arborea no habitat natural.

\section{Pithecellobium tortum Mart.}

Pithecellobium tortum é uma arbusto que ocorre próximo à praia, tem porte prostrado, com ramos muito tortuosos e próximos ao solo, formando pequenas moitas. As flores são brancas, hermafroditas, nectaríferas, emitem um odor agradável e doce e são reunidas em sinflorescências.

A floração ocorre em outubro/novembro e a maturação dos frutos em agosto/setembro com a planta quase totalmente destituída de sua folhagem. Os frutos são legumes helicoidais 


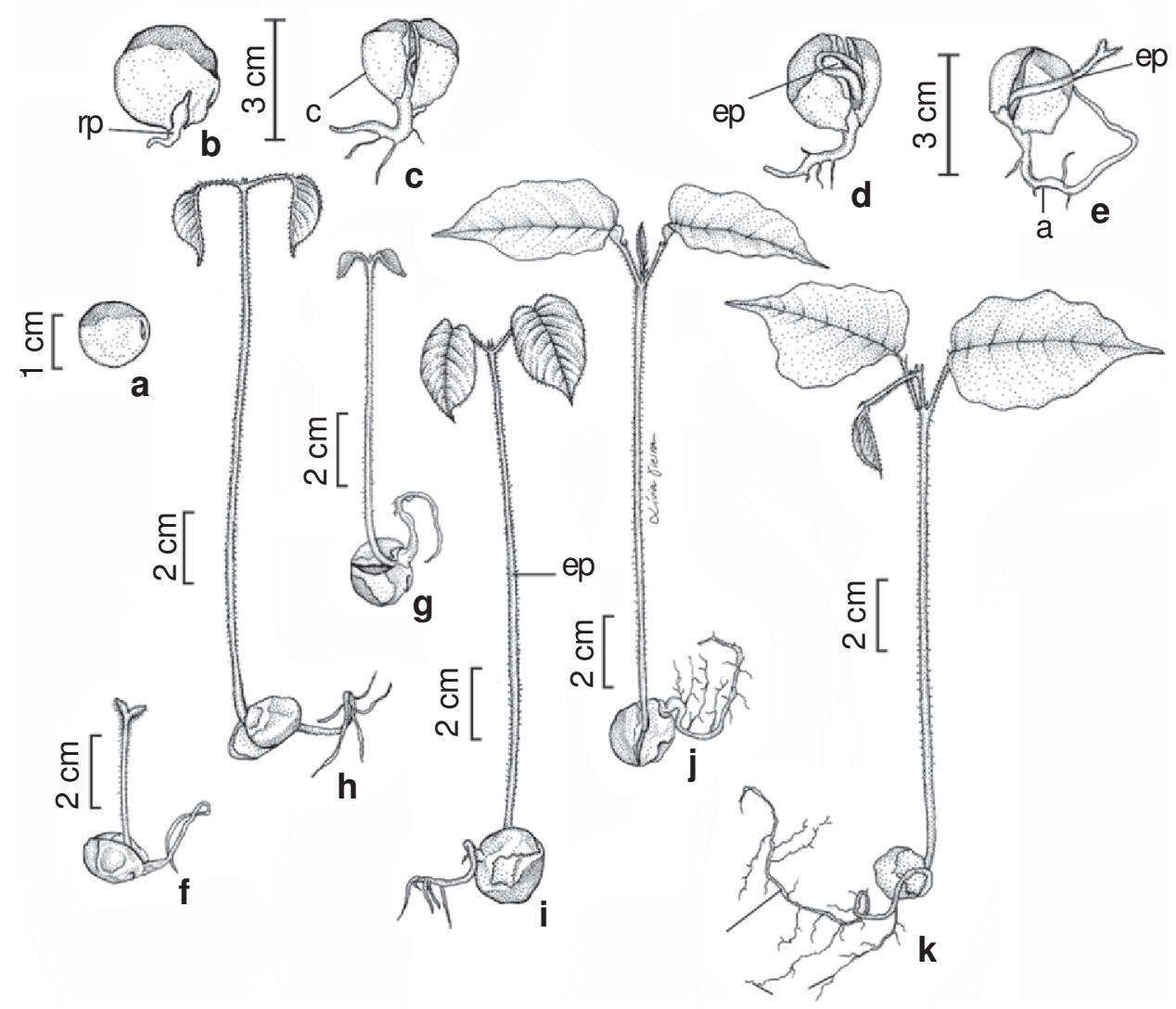

Figura 6 - Desenvolvimento da plântula de Ormosia arborea (Vell.) Harms. - a. semente; b. semente com 9 dias, surgindo a raiz principal (rp); c. plântula com 12 dias, mostrando cotilédones (c); d-f. plântulas com 13 dias a 16 dias mostrando o desenvolvimento do epicótilo (ep); g-i. plântulas com 20 a 26 dias, mostrando o epicótilo (ep) e os eófilos; j. plântula com os eófilos totalmente desenvolvidos, notar a intensa pilosidade do epicótilo e surgimento de raízes secundárias; k. plântula com 60 dias, $20 \mathrm{~cm}$ de altura, mostrando primeiro e segundo pares de eófilos, raiz principal (rp) e raízes secundárias (rs). Observar nesta fase o início da senescência dos cotilédones.

deiscentes, de coloração verde escura que passa a marrom com a maturidade, possuindo um odor forte e agradável (Fig. $7 \mathrm{a}, \mathrm{b})$. Os frutos apresentam em média 3,7 $\mathrm{cm}$ de comprimento $(\mathrm{N}=28, \mathrm{dp}=0,49)$ e contêm em média 14 sementes $(\mathrm{N}=28$, $\mathrm{dp}=7,6$ ). Estas são ovóides, de coloração acinzentada com uma mancha escura no centro da semente, no sentido longitudinal, e têm média de $0,5 \mathrm{~cm}$ de comprimento $(\mathrm{N}=50$, $\mathrm{dp}=0,05$, Fig. 8a). Nos frutos analisados foram observados aborto e predação de sementes.

\subsection{Desenvolvimento das plântulas de Pithecellobium tortum}

O percentual de germinação registrado em P. tortum foi de $75 \%(\mathrm{~N}=20)$. A germinação é fanerocotiledonar com emissão da raiz principal em cerca de quatro dias (Fig. 8b). Após cinco dias, inicia-se o desenvolvimento do hipocótilo (Fig. 8c). A plântula com 13 dias já mostra o início de liberação dos cotilédones do tegumento, nesta fase o hipocótilo cresce bem rápido, tem superfície lisa e aspecto frágil (Fig. 8d, e). Com 15 dias os cotilédones estão 

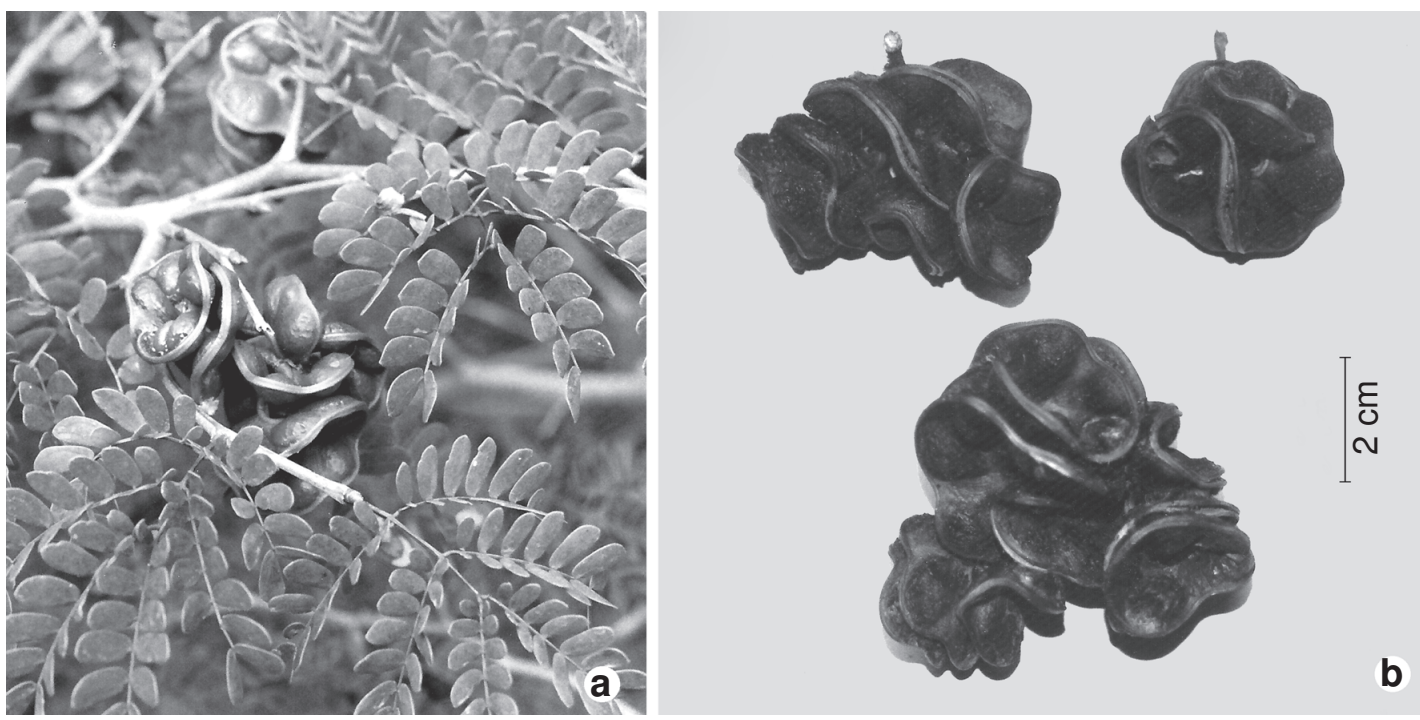

Figura 7 - Frutos de Pithecellobium tortum Mart. - a. em desenvolvimento; b. variação de tamanho em frutos abertos.

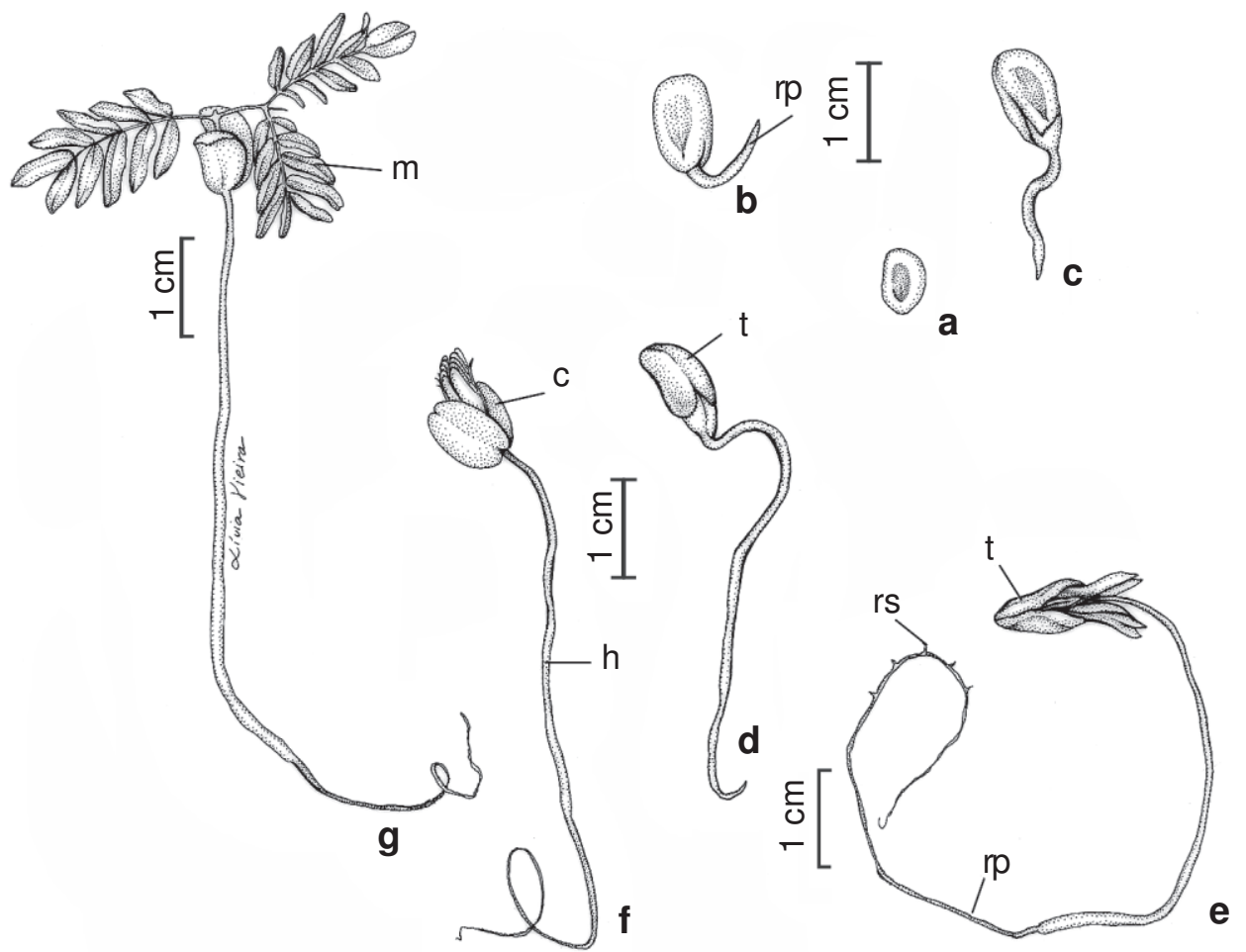

Figura 8 - Desenvolvimento da plântula de Pithecellobium tortum Mart. - a. semente; b. semente com cerca de 4 dias de germinada emitindo a raiz principal (rp); c. plântula com 5 dias mostrando início de emissão do hipocótilo; d. plântula com 10 dias com o hipocótilo bem alongado e cotilédones protegidos pelo tegumento (t); e. plântula com 15 dias mostrando início de liberação dos cotilédones do tegumento (t), raiz principal longa (rp) e raízes secundárias (rs); f. plântula com 16 dias, mostrando os cotilédones livres (c) e início do surgimento dos metáfilos; g. plântula com 30 dias, 12 cm de altura, com metáfilos $(\mathrm{m})$ totalmente distendidos. 
completamente expandidos e observa-se o início do surgimento dos metáfilos paripenados (Fig. 8f). Os cotilédones são pequenos $(0,8 \mathrm{~cm}$ de comprimento), verdes e carnosos. Com 25 dias a plântula atinge $12 \mathrm{~cm}$ de altura e tem os folíolos completamente distendidos (Fig. 8g). Com cerca de 30 dias a plântula perde os cotilédones. Não foram registradas plântulas no habitat natural.

\section{Swartzia apetala Raddi var. apetala}

Swartzia apetala var. apetala é um arbusto encontrado no cordão arenoso interno da restinga de Maricá. As flores são zigomorfas, hermafroditas, apétalas, odoríferas, possuem cerca de $1,0 \mathrm{~cm}$ de comprimento e reúnem-se em inflorescências racemosas. A floração ocorre de novembro a fevereiro e a frutificação a partir de abril a julho. Os frutos são legumes elípticos, de coloração verde (nos três primeiros meses de seu desenvolvimento), passando a alaranjados (do terceiro mês até a deiscência), tornando a planta muito atrativa à longa distância. Os frutos têm em média $2,7 \mathrm{~cm}$ de comprimento $(\mathrm{N}=32, \mathrm{dp}=0,35)$ e possuem uma $(63 \% ; \mathrm{N}=55)$, duas $(32,7 \%$; $\mathrm{N}=55)$ ou três sementes $(3,6 \% ; \mathrm{N}=55)$. Observa-se que o comprimento do fruto não varia com a presença de uma ou mais sementes (Fig. 9a-c). Ocasionalmente foram observadas sementes abortadas (Fig. 9d).

As sementes apresentam forma próxima à ovóide, são de cor preta com um tegumento brilhante e possuem um arilo de cor branca na parte superior da semente (Fig. 10a). As sementes têm em média $1,8 \mathrm{~cm}$ de comprimento $(\mathrm{N}=56, \mathrm{dp}=0,51)$.

\subsection{Desenvolvimento das plântulas de Swartzia apetala var. apetala}

$O$ percentual de germinação registrado em $S$. apetala var. apetala foi de $93 \%$ $(\mathrm{N}=35)$. A germinação é criptocotiledonar, com emissão da raiz principal em torno de 21 dias (Fig. 10b). As sementes quando colocadas para germinar absorvem muita água, dobrando seu tamanho (Fig. 10c). A plântula com cerca de 20 dias apresenta a raiz principal bem desenvolvida alcançando até $5,0 \mathrm{~cm}$ de comprimento, nesta fase, já se
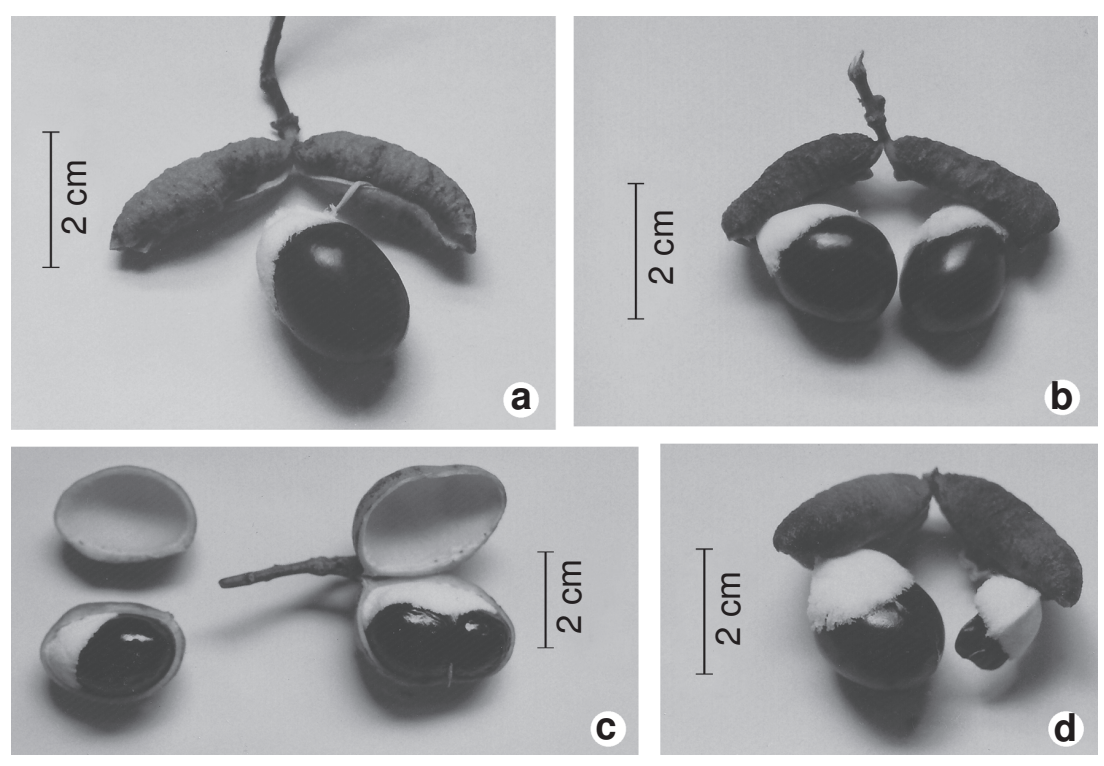

Figura 9 - Frutos de Swartzia apetala Raddi var. apetala - a. com uma só semente pêndula pelo funículo, notar a cor preta brilhante contrastando com o arilo branco; b. com duas sementes; c. similaridade dos tamanhos de frutos com uma e duas sementes; d. fruto mostrando aborto de uma das sementes. 

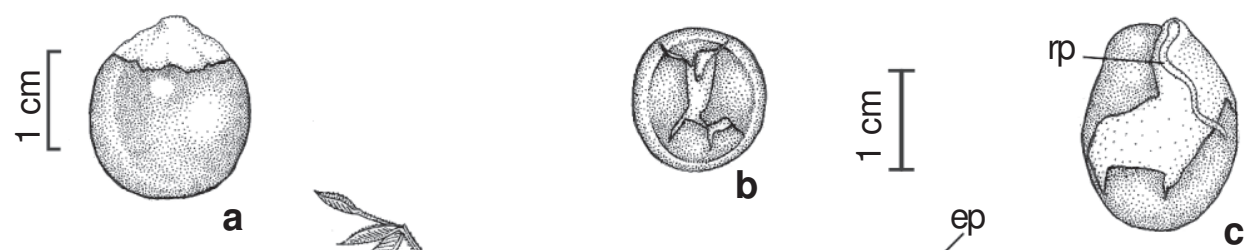

ca

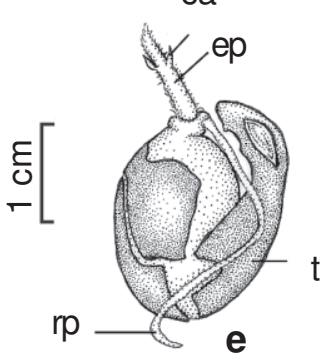

.
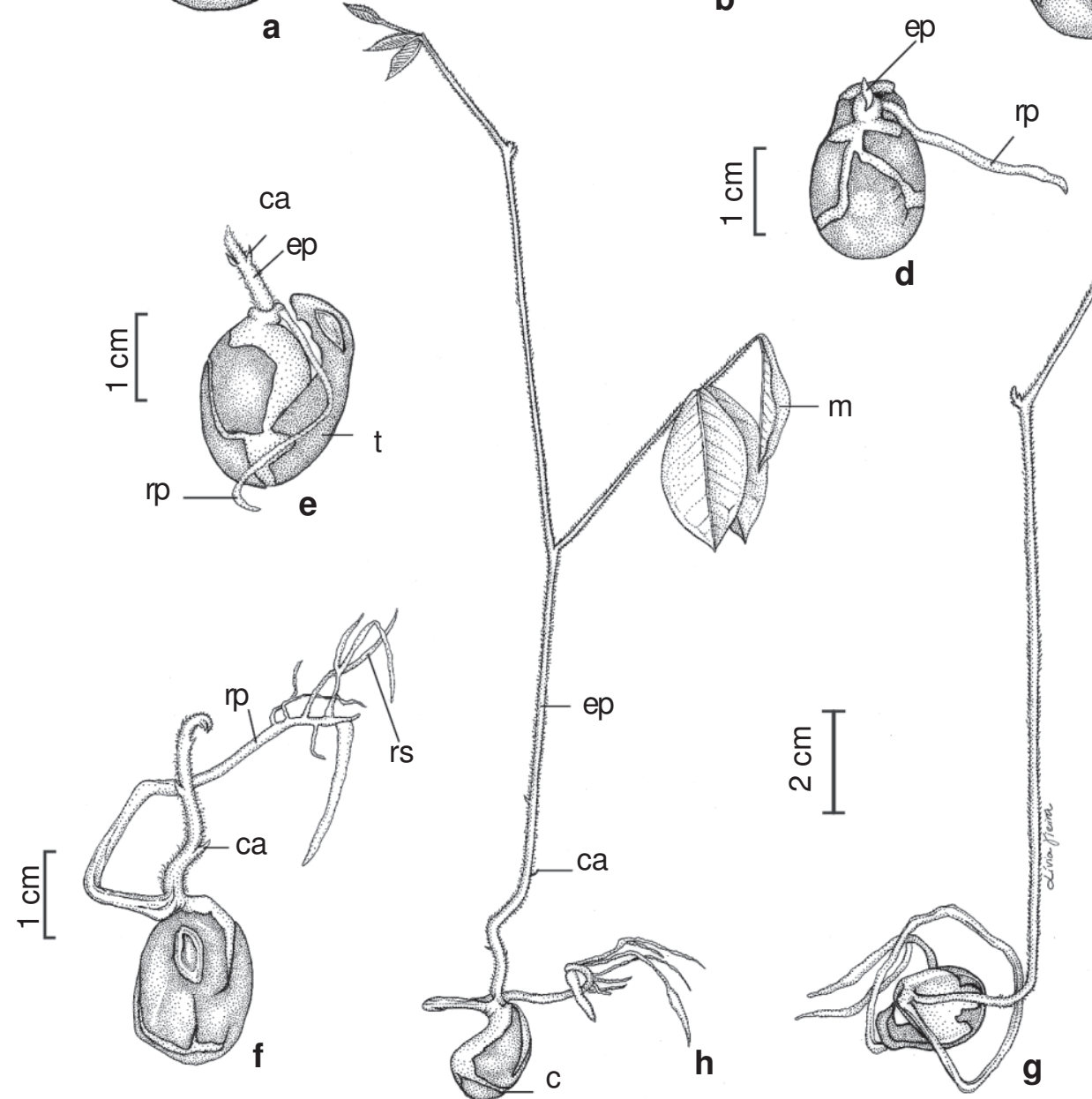

C

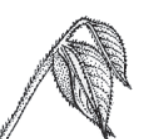

h

g

Figura 10 - Estudos do desenvolvimento da plântula de Swartzia apetala Raddi var. apetala - a. semente com arilo; b. semente com o tegumento rachado; c. semente com 21 dias de germinada, emitindo a raiz principal (rp); d. plântula mostrando o início da emissão do epicótilo (ep) e raiz principal (rp); e. plântula com 24 dias evidenciando o epicótilo que apresenta catáfilos (ca); f. plântula com 30 dias, com três catáfilos (ca) no epicótilo e raízes secundárias (rs); g. plântula com 40 dias, $13 \mathrm{~cm}$ de altura, mostrando epicótilo muito piloso e surgimento dos mesófilos; h. plântula com 60 dias, mostrando metáfilos (m), epicótilo piloso, comprido e fino (ep), catáfilos (ca) e cotilédones que começam a diminuir de tamanho (c).

observa nas sementes germinadas o início da emissão do epicótilo (Fig. 10d). Este é cilíndrico, piloso, de cor verde escura, apresenta crescimento lento e produz de três a quatro catáfilos alternos (Fig. 10e-f). A plântula com 26 dias apresenta grande crescimento de raízes secundárias (Fig. 10f). Com 50 dias o epicótilo piloso é bem fino e frágil e bifurca-se, surgindo os eófilos (Fig. 10g). A plântula com cerca de dois meses apresenta quase sempre uma bifurcação no epicótilo, de onde surgem hastes com outros metáfilos. Os metáfilos são trifoliolados, sendo os folíolos sésseis e pulvinulados. A plântula nesta fase tem os cotilédones murchos e $20 \mathrm{~cm}$ de altura (Fig. 10h). Após 90 dias, os cotilédones desaparecem. No habitat natural não foram observadas plântulas de $S$. apetala var. apetala. 


\section{Discussão e Conclusões}

Canavalia rosea, Ormosia arborea, Pithecellobium tortum e Swartzia apetala são altamente atrativas pelas suas flores, destacando-se, ainda, pela beleza de seus frutos e sementes. Todas as espécies apresentam frutos deiscentes e sementes com dispersão autocórica. Em S. apetala, o contraste de cor entre o pericarpo e a semente, e a presença de um vistoso arilo branco sugerem dispersão biótica, possivelmente por pássaros (Pijl 1972).

A existência de estudos sobre plântulas de leguminosas brasileiras é escassa, muito embora se destaquem os trabalhos de Silva et al. (1988), Lima (1989-90), Oliveira \& Beltrati (1992), Pereira (1992), Oliveira (1999; 2001) e Rodrigues \& Tozzi (2007a,b). Para outras famílias do ambiente restinga, destacam-se os trabalhos de Correia (2002), Correia et al. (2005) e Correia \& Lima (2006), em espécies de Bignoniaceae e Ferreira \& Correia (2005), Ferreira et al. (2006) em espécies de Bromeliaceae.

Leguminosae apresenta uma grande diversidade no que se refere ao tipo de germinação das sementes. Neste estudo foram registradas espécies com germinação criptocotiledonar (O. arborea e $S$. apetala) e fanerocotiledonar (C. rosea e $P$. tortum). Para Ormosia há registros de espécies com germinação criptocotiledonar e fanerocotiledonar (Rodrigues \& Tozzi 2007b), ao passo que em Swartzia parece haver uma uniformidade com relação ao tipo de germinação, com registros de germinação criptocotiledonar também para S. langsdorffii Raddi (Oliveira 2001) e $S$. polyphylla (Silva et al. 1988).

Com relação aos experimentos de germinação realizados neste trabalho, não foi observado nenhum fator que impedisse a germinação das sementes, tendo-se registrado percentuais elevados de germinação (75\% a $100 \%$ ) em sementes recém coletadas de todas as espécies de leguminosas testadas. A germinação das espécies em estudo ocorreu num período de 2-10 dias (C. rosea, P. tortum e O. arborea) a 21 dias (S. apetala).
Os experimentos realizados em C. rosea mostraram que as sementes apresentaram alto poder germinativo em todos os substratos testados. Esses resultados diferem daqueles de Lucas \& Arrigoni (1992), que obtiveram para a espécie média pouco expressiva de germinação, em torno de $30 \%$, tanto em presença de luz quanto no escuro. Ainda segundo os autores, regimes de alternância de temperatura em termoperíodos de 12 horas promovem a germinação na luz e no escuro, mas, mesmo nestes casos, o máximo obtido foi inferior a $50 \%$ de germinação.

Os experimentos de germinação com sementes de $C$. rosea encontradas na areia e que estavam expostas a todas as intempéries das zonas halófitas e psamófitas-reptantes revelaram um percentual alto de germinação (84\%), mostrando que as sementes não perderam o poder germinativo. Essas zonas (próximas ao mar) são altamente instáveis e estressantes para as plantas, devido à salinidade do solo, alta radiação solar, deficiência de nutrientes, rajadas de areia, dessecação pelo vento, ação humana, herbivoria e, principalmente, mobilidade do substrato que causa o soterramento de plantas e a remoção por ações eólicas e erosivas do mar (Araújo \& Henriques 1984, Lee \& Ignaciuk 1985, Maun 1994). Segundo Maun (loc. cit.) a grande variabilidade de microhabitats, gerada pela ação do vento e das ondas do mar, cria severas e incertas condições para a germinação de sementes, emergência de plântulas e o estabelecimento destas.

As espécies que ocupam as zonas halófita e psamófita-reptante apresentam adaptações especiais que permitem resistir e sobreviver a episódios de soterramento, sendo a capacidade das plantas de tolerar o soterramento variável entre espécies e dependente da extensão e duração do soterramento, do estágio de desenvolvimento e ainda da forma de vida das espécies vegetais (Maun 1994). C. rosea manteve os altos índices de germinação, com emergência, após experimentos de soterramento até $10 \mathrm{~cm}$ de 
profundidade. Fáveri \& Castellani (1998) soterraram, experimentalmente, sementes já germinadas de $C$. rosea. As plântulas submetidas aos experimentos emergiram após soterramento de 5 e $10 \mathrm{~cm}$ de profundidade, mas nenhuma plântula emergiu de 15 a $20 \mathrm{~cm}$. Nossos resultados confirmam os de Fáveri \& Castellani (1998) e acrescentam ainda a capacidade das sementes de germinar, mesmo soterradas até $10 \mathrm{~cm}$.

Segundo Moreno-Casasola (1986) estudos de comunidades vegetais mostraram que há uma estreita correlação entre o movimento da areia e a composição de espécies, cobertura e densidade. O soterramento elimina espécies intolerantes, reduz a abundância relativa de espécies pouco tolerantes e aumenta a abundância de espécies tolerantes. Para Maun (1994), plântulas podem se beneficiar do soterramento devido a muitos fatores como: mais espaço para o crescimento da raiz, mais nutrientes no novo substrato, mudanças na biota, melhor disponibilidade de umidade e melhor microhabitat. $\mathrm{O}$ autor relatou que plântulas de Panicum virgatum L., emersas após soterramentos profundos, demonstram melhores possibilidades de sobrevivência, por causa do melhor acesso à umidade do solo. Acrescentou ainda, que o soterramento confere vantagens para sementes e plântulas nas dunas da costa. Sementes soterradas podem não só escapar da predação, mas também encontrar condições melhores para germinação, o que provavelmente acontece com as sementes de $C$. rosea na área de estudo da restinga de Maricá.

Os altos percentuais de germinação obtidos para as sementes de $O$. arborea, escarificadas ou não, num período de 7 a 13 dias, diferem dos resultados obtidos por Zamith \& Scarano (2004) que classificaram a espécie como de germinação média $(1-74 \%)$ e lenta (14-97 dias), sem detalhar se as sementes foram ou não escarificadas.

Para outras espécies de Swartzia os índices de germinação foram mais baixos do que os obtidos para S. apetala, a saber: $48 \%$ em germinador e $36 \%$ em estufa de sombrite, para S. langsdorffii (Oliveira 2001) e 54\% para S. polyphylla (Silva et al. 1988).

A presença de nódulos radiciais em $C$. rosea ocorreu em plântulas com cerca de um mês, tanto na raiz principal quanto nas raízes secundárias, entretanto em $S$. apetala estes nódulos aparecem em plantas aos noves meses, somente nas raízes secundárias. Segundo Oliveira (2001) em plântulas ou plantas jovens de leguminosas é comum já serem observados nódulos radiciais, tanto na raiz principal quanto nas raízes secundárias. A autora registrou nódulos radiciais nas raízes secundárias de plantas jovens de $S$. langsdorffii, a partir dos 13 meses.

Nas espécies estudadas, somente $C$. rosea apresentou plântulas no habitat natural. Deve ser ressaltada a importância de se conhecer a morfologia das sementes e das plântulas, uma vez que só foi possível identificálas no ambiente natural após comparação com as plântulas cultivadas durante os experimentos de germinação em laboratório.

\section{Agradecimentos}

À bióloga e desenhista Lívia Botinhão Vieira dos Santos, pela confecção e ao biólogo e mestre Eduardo Assis Abrantes, pela disposição das pranchas de germinação das espécies em estudo.

\section{REFERÊNCIAS BIBLIOGRÁFICAS}

Araújo, D. S. D. \& Henriques, R. P. B. 1984. Análise florística das restingas do Rio de Janeiro. In: Lacerda, L. D.; Araújo, D. S. D.; Cerqueira, R. \& Turcq, B. (org.). Restingas, origem, estrutura, processos. Universidade Federal Fluminense. (CEUFF). Niterói, Rio de Janeiro. Pp. 159-194.

Araújo, S. D.; Costa, A. F.; Oliveira, A. S. \& Moura, R. L. 2001. Florística e padrões fitogeográficos. In: Costa, A. F. \& Dias, I. C. A. (org.). Flora do Parque Nacional da restinga de Jurubatiba e arredores, Rio de Janeiro, Brasil: listagem, florística e 
fitogeografia. Série Livros 8. Museu Nacional/UFRJ. Rio de Janeiro. Pp. 156-165.

Arroyo, M. T. K. 1981. Breeding systems and pollination biology in Leguminosae. In: Polhih, R. M. \& Raven, P. H. (eds.). Advances in legume systematic. Royal Botanic Gardens, Kew, 1048p.

Barros, F.; Mello, M. M. R. F.; Chiea, S. A. C., Kirizawa, M., Wanderley, M. G. L. \& Jung-Mendaçolli, S. L. 1991. Flora Fanerogamica da Ilha do Cardoso: caracterização geral da vegetação e listagem das espécies ocorrentes. Instituto de Botânica, São Paulo, Vol. I, 184p.

Correia, M. C. R. \& Lima, H. A. 2006. Germinação e caracterização de seis espécies de Bignoniaceae na restinga de Maricá - RJ. Resumos da XXV Jornada Fluminense de Botânica (em cd).

Correia, M. C. R. 2002. Biologia da reprodução de quatro espécies de Bignoniaceae da restinga de Maricá, RJ. Tese de Doutorado. Museu Nacional, Universidade Federal do Rio de Janeiro (UFRJ). Rio de Janeiro. 194p.

Correia, M. C. R.; Pinheiro, M. C. B. \& Lima, H. A. 2005. Produção de frutos e germinação das sementes de Anemopaegma chamberlaynii Bur. \& K. Schum. (Bignoniaceae) - Um registro de poliembrionia. Sitientibus Série Ciências Biológicas 5(2): 68-71.

Fáveri, S. S. \& Castellani, T. T. 1998. Efeitos do soterramento no desenvolvimento e estabelecimento de plântulas de Canavalia rosea. In: Resumos dos Anais do IV Simpósio de Ecossistemas Brasileiros. Vol. III, Águas de Lindóia, SP, Brasil. Pp. 104-115.

Ferreira, M. M. \& Correia, M. C. R. 2005. Aspectos morfológicos do fruto da semente e das plântulas de Pouteria caimito Ruiz \& Pavon (Sapotaceae). Resumos da XXIV Jornada Fluminense de Botânica (em cd).

Ferreira, M. M.; Correia, M. C. R. \& Gomes, R. 2006. Aspectos morfológicos do fruto, da semente e das plântulas de Bromelia antiacantha Bertol. (Bromeliaceae). Resumos da XXV Jornada Fluminense de Botânica (em cd).

Gentry, A. H. 1982. Neotropical floristic diversity: phytogeographical connections between Central and South America. Pleistocene climatic fluctuations or an accident of the Andean orogeny? Annals of the Missouri Botanical Garden 69: 557593.

Lee, J. A. \& Ignaciuk, R. 1985. The physiological ecology of strandline plants. Vegetatio 62: 319-326.

Lima, H. C. 1989-90. Tribo Dalbergieae (Leguminosae Papilionoideae) morfologia dos frutos, sementes e plântulas e sua aplicação na sistemática. Arquivos do Jardim Botânico do Rio de Janeiro 30: $1-42$.

Lucas, N. M. C. \& Arrigoni, M. F. 1992. Germinação de sementes de Canavalia rosea (Sw.) DC. (Fabaceae). Revista Brasileira de Botânica 15(2): 105-112.

Maun, M.A. 1994. Adaptations enhancing survival and establishment of seedlings on coastal dune systems. Vegetatio 111: 59-70.

Moreno-Casasola, P. 1986. Sand movement as a factor in the distribution of plant communities in a coastal dune system. Vegetatio 65:67-76.

Oliveira, D.M.T. \& Beltrati, C.M. 1992. Morfologia e desenvolvimento das plântulas de Inga fagifolia e I. urugüensis. Turrialba 42:306-313. 1999. Morfologia de plântulas e plantas jovens de 30 espécies arbóreas de Leguminosae. Acta Botânica Brasílica 13(3): 263-269.

.2001. Morfologia comparada de plântulas e plantas jovens de leguminosas arbóreas nativas: espécies de Phaseoleae, Sophoreae, Swartzieae e Tephrosieae. Revista Brasileira de Botânica 24(1): 85-97.

Oliveira, E. C. 1993. Morfologia de plântulas florestais. In: Aguiar, I.B.; PinãRodrigues, F.C.M. \& Figliolia, M.B. 
(org.). Sementes Florestais Tropicais. Associação Brasileira de Tecnologia de Sementes. Brasília, Distrito Federal. Pp. 175-213.

Parra, P. G. 1984. Estudio de la morfologia externa de plántulas de Calliandra gracilis, Mimosa arenosa, Mimosa camporum y Mimosa tenuiflora. Revista de la Facultad de Agronomia. Universidad Central de Venezuela (MaracayVenezuela) (1-4): 311-350.

Pereira, M. C. A.; Araújo, D. S. D. \& Pereira, O.J. 2001. Estrutura de uma comunidade arbustiva da restinga da Barra de Maricá - RJ. Revista Brasileira de Botânica 24(3): 273-281.

Pereira, O. J. \& Araújo, D. S. D. 2000. Análise florística das restingas dos estados do Espírito Santo e Rio de Janeiro. In: Esteves, F. A. \& Araújo, L. D. (org.). Ecologia de restingas e lagoas costeiras. NUPEM/UFRJ, Macaé, Rio de Janeiro, Brasil. Pp. 25-63.

Pereira, T. S. 1992. Germinação de sementes de Bauhinia forficata Link. (Leguminosae Caesalpinoideae). Revista Brasileira de Sementes 14(1): 77-82.

Pijl, L. van der. 1972. Principles of dispersal in higher plants. Springer-Verlag, New York, 161p.
Rodrigues, R. S. \& Tozzi, A. M. G. A. 2007a. Morfologia de plântulas no clado Vatairea (Leguminosae, Papilionoideae). Rodriguésia 58(2): 221-229.

Rodrigues, R. S. \& Tozzi, A. M. G. A. 2007b. Morfologia de plântulas de cinco leguminosas genistóides arbóreas do Brasil (Leguminosae-Papilionoidae). Acta Botanica Brasilica 21(3): 599-607.

Silva, D. C. 2003. Morfologia, recrutamento e estabelecimento de plântulas em comunidade em regeneração da reserva biológica de Poços das Antas - Silva Jardim, RJ. Dissertação de Mestrado. Programa de Pós-graduação em Botânica. Museu Nacional, Universidade Federal do Rio de Janeiro. Rio de Janeiro. 143p.

Silva, J. G. \& Oliveira, A. S. A. 1989. A vegetação da restinga no Município de Maricá - RJ. Acta Botanica Brasilica (Supl.) 3(2): 253272.

Silva, M. F.; Goldman, G. H.; Magalhães, F. M. \& Moreira, F. W. 1988. Germinação natural de 10 espécies arbóreas da Amazônia. I. Acta Amazônica 18(1-2): 9-26.

Zamith, L. R. \& Scarano, F. R. 2004. Produção de mudas de espécies das Restingas do município do Rio de Janeiro, RJ, Brasil. Acta Botanica Brasilica 18(1): 161-176. 